\title{
The Effect of Project-Based Learning on L2 Spoken Performance of Undergraduate Students in English for Business Class
}

\author{
Achmad Yudi Wahyudin \\ STBA Teknokrat, Bandar Lampung
}

\begin{abstract}
Project-based Learning (PBL) has become the central part of ESP practice in higher education. The present study tried to confirm the questions whether the students' foreign language (L2) oral performance in English for Business (EFB) Class is significantly affected after PBL is tailored. The study conducted for a semester used an experimental design with the total of 60 students as participants. Before the learning process began, the students were assigned randomly to experimental class (learning EFB through PBL) and control class (learning EFB through Presentation, Practice, Production). In both classes, a business presentation was employed as an oral test in order to reveal the difference of the $L 2$ spoken performance between experimental class and control class. The finding in this study pointed out that the students who learn EFB through PBL outperformed the students who learned EFB through PPP. Since the finding of this study confirms numerous previous studies conducted in the same area, it is recommended that practitioners apply PBL as an alternative way to teach ESP class, especially at the undergraduate level.
\end{abstract}

Keywords: ESP, undergraduate student, project-based learning, spoken performance, quasi-experimental.

\section{INTRODUCTION}

The development of teaching ESP has been a salient concern since learners require different needs that should be served by the curriculum implemented by all higher education institutions in Indonesia. Producing graduates (of various majors) equipped with foreign language ability, particularly English, has become a necessity in order to cope with the current $21^{\text {st }}$-century demand (Andrade, 2016) where professional and multilingual competencies are urgently required (Suherdi, 2012). Given this current situation, ESP practitioners are required to be more aware of the challenges and to be more innovative in conducting ESP practice. However, on the practical level, several considerable problems which mostly occur in multiple layers for Indonesian ESP teachers. At the institutional level, limited teaching and learning resource have been the major issue (Medrea \& Rus, 2012) as well as the number of class participants that can exceed more than 50 students. At human resource level, ESP teachers seem to have inadequate professional development opportunities to cope with the challenges and demands nowadays (Khanh, 2015). In addition, at the classroom level, ESP learners are likely to have poor language proficiency (see Ibrahim, 2010; Robinson, 2013) due to the failure of teaching/learning happened at the secondary level (see Unal et.al., 2014). They also lack motivation in the classroom. Hence, the attainment of learning objectives is unsuccessful, especially for both content and the L2 mastery (Nakaya \& Murota, 2013). Most importantly, developing L2 oral proficiency becomes the main issue for ESP learners in EFL countries since they rarely talk English on a daily basis.

The present study, nevertheless, does not address all problems that occur in the practice of ESP stated above. It is more concerned with the attempt to improve the ESP students' L2 oral communication competence in classroom level. Among the current pedagogical trends that have become the central part of the $21^{\text {st }}$ century English education, PBL has caught ESP practitioners' attention. PBL is an instructional method that puts forward the learner-centeredness and provides abundant opportunity to deal with meaningful and authentic communication. PBL promotes $21^{\text {st }}$-century skill as it fosters the use of technology that becomes the central part of ESP classroom (Tyagi \& Kannan, 2013) and the integration of ICT competencies (Dooly \& Masats, 2011) such as operating word process, editing slides, and video, and utilizing various softwares. It is believed that PBL functions as a bridge between using English in class and using English in real life situations outside the class. Projects accomplishment makes the learners work collaboratively to plan, organize, negotiate, make their points, and arrive at a consensus on issues such as what tasks to perform, who will be responsible for each task, and how information will be researched and presented (Bas, 2008). Due to the collaborative nature of project work, the development of L2 oral proficiency occurs even among learners at low levels of language proficiency (See Al-Tamimi \& Attamimi, 2014; Rodrigo, 2014).

The implementation of PBL in the current study employed the framework adopted from Dooly \& Masats (2011), Noom-Ura (2013) and Penrod, Tucker, and Hartman (2015). In order to accomplish the project the classroom process requires three core competencies: 
Communicative Competencies; (2) ICT Competencies; (3) Business Presentation. The framework of PBL is mainly adopted from Dooly \& Masats (2010) since it fits the context of EFB in the research site. The business presentation skill is adopted from Penrod et al. (2015) since their model provides the tangible and measurable process for business presentation evaluation. In relation to the project used in this study, producing a video is employed since it has been widely used and considered effective to serve the nature of PBL and ESP learning objectives (See Nikitina, 2010; Foss, Carney, McDonald, and Rooks, 2008;). The challenging projects are used in order to arouse the students' motivation and self-direction (Becket, 2002). The attainment of the project can be seen in the following figure:

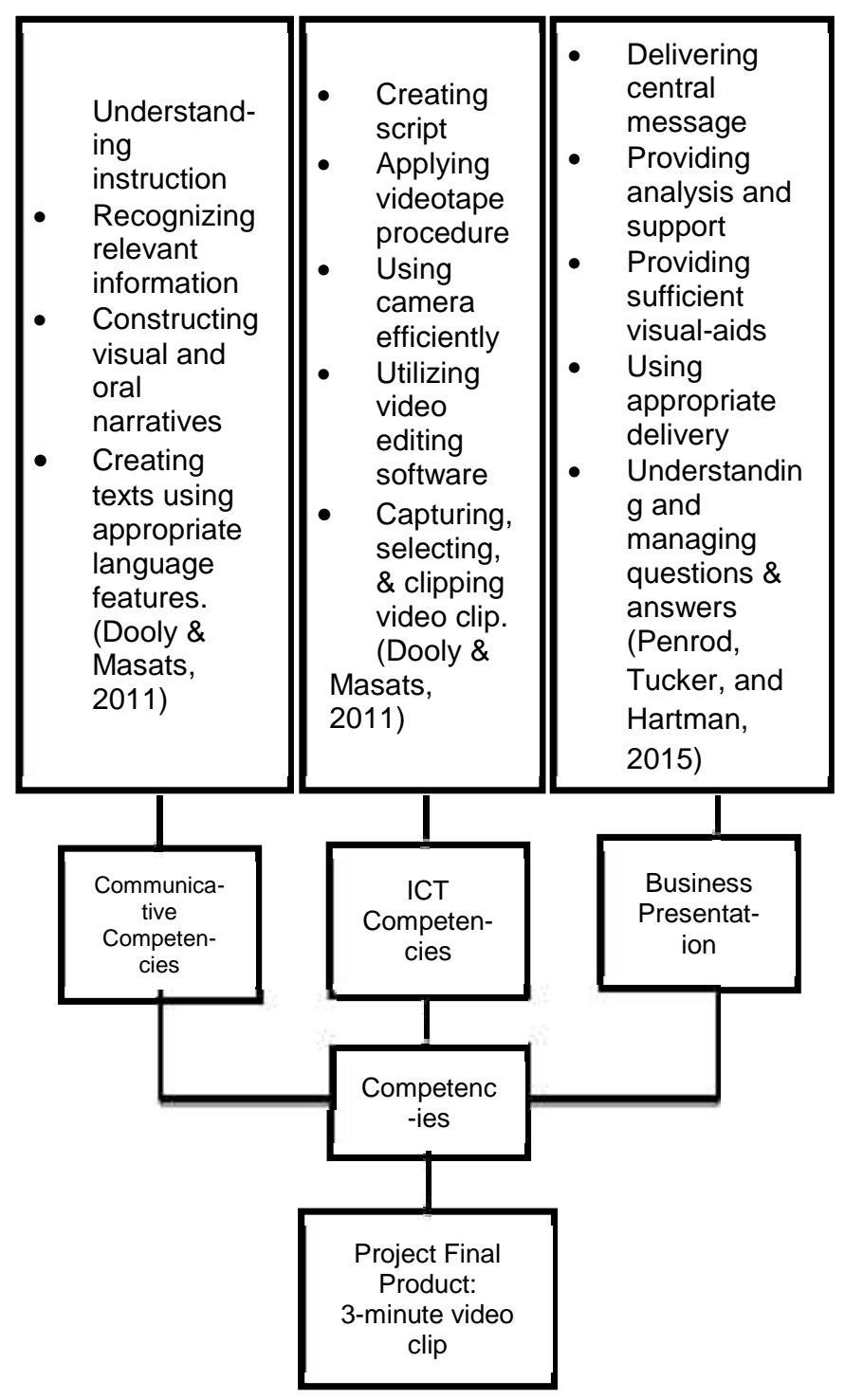

Figure 1.1 The framework of project-based completion

Extensive studies have been conducted to explore and confirm the benefits of integrating PBL to ESP and
EFL contexts in the last decade. Some studies were done quantitatively (Mamakou \& Grigoriadou, 2010; Meksophawannagul, 2015; Affandi \& Sukyadi, 2016; Alsamani \& Daif-Allah, 2016) and some were done qualitatively (Foss et al., 2008; Dooly \& Masats, 2010; Nikitina, 2010; Khanh, 2015). For examples, Mamakou \& Grigoriadou (2010) employed an E-project-based approach in ESP learning in Greece. From their study, PBL seems to be effective in fostering collaborative work, the use of the internet, and acquisition of knowledge and skills. In Indonesian context, Affandi \& Sukyadi (2016) conducted an experimental study to compare the effectiveness of Project-based and Problem-based learning at tertiary level. It is revealed that both methods share similar effects in terms of critical thinking and writing ability. On the other hand, Khanh (2015) discussed the integration of PBL into current ESP courses as an alternative to overcome the problems existed in Vietnam. Dooly and Masats (2010) conducted the extensive study to the use of PBL in EFL classroom. Their study resulted in a model that can be integrated into an EFL classroom as an effective model. The present study adapted the model established by Dooly \& Masats (2011) since it gives clear and tangible learning procedure for the attainment of ESP objectives. Since numerous studies (Mamakou \& Grigoriadou, 2010; Meksophawannagul, 2015; Affandi \& Sukyadi, 2016) did not entirely concern the aspect of L2 oral performance, the present study attempts to explore the effect of PBL on the aspects of speaking such as accent, grammar, vocabulary, fluency, and comprehension.

\section{METHODS}

The present study was carried out in one of higher education institutions in Bandar Lampung, Indonesia. This institution concerns the demand for a local workforce where stakeholders need graduates who are able to actively communicate with the customer and promote goods and services in both national and foreign languages. In order to cope with this demand, English for Business (EFB) program has been offered for non-English Departments for the second-semester students majoring in informatics system and computer engineering. The classroom process mainly occurred in the classroom equipped with ICT equipment such as a monitor, multimedia computer, and sound system.

Control group pre-test and post-test designs were employed in this study in which experimental groups and control groups were used to compare the means of L2 spoken performance between students who studied in PBL class and those who studied in Presentation, Practice, and Production (PPP) class. The teaching and learning process happened once per week for 100 minutes for 16 meetings.

The level of L2 proficiency of the participants is considered low and average based on the grade of prerequisite subjects they have taken in the first semester. The sample consisted of 60 students selected randomly out of 250 students. In order to serve the objective of the study, 
60 students were assigned randomly to one experimental class and one control class. They were also assigned based on the result of homogeneity test to measure the equality of the students' ability. The students' age ranges from 20-22 years old and none of the students take any English courses outside of the class.

The present study used a business presentation for pre-test and post-test as the way to measure the students' L2 spoken performance. The same test was employed in both experimental and control classes to confirm whether the students' L2 spoken performance in those classes differs significantly. The students' L2 spoken performance was measured based on the rating scale established by Hughes (2003). The adopted scoring criteria concerning aspects: accent, grammar, vocabulary, fluency, and comprehension. Those aspects range from 1 to 6 . During the test, the students were asked to have a business presentation in pairs for 10 minutes and question and answer (Q\&A) session (Penrod, Tucker, \& Hartman, 2015) in front of the class for about 10 minutes and their performance was scored by two raters.

The data were analyzed with SPSS (ver.15). Numerous analyses were done in order to ensure the credibility of the data. First, normality test was carried out to make sure whether the score distribution is normal. Second, random test and homogeneity test were also used to confirm whether the data is random and both classes have equal ability. The formulated hypothesis can be seen as follows:

$\mathrm{H}_{0}$ : There is no significant difference in L2 Performance between students treated in experimental and students treated in control class

$\mathrm{H}_{1}$ : There is no significant difference in L2 Performance between students treated in experimental and students treated in control class

\section{RESULTS AND DISCUSSION}

\subsection{The Improvement of Students' L2 Spoken} Performance

The length of this study was six months, and it stopped when the data gathered had been sufficient to answer the overarching research question. The experimental class was treated with PBL, and the control class was treated with PPP. The improvement of the students' L2 oral performance was seen in the difference between the mean score of the pretest and the mean score of post-test.

Table 3.1 Descriptive statistics for experimental and control class

\begin{tabular}{lllllll}
\hline No & $\begin{array}{l}\text { Teaching } \\
\text { method }\end{array}$ & N & Means & $\begin{array}{l}\text { Standard } \\
\text { deviation }\end{array}$ & $\begin{array}{l}\text { Minimum } \\
\text { score }\end{array}$ & $\begin{array}{l}\text { Maximum } \\
\text { score }\end{array}$ \\
\hline 1 & PBL & 30 & 2.39 & .33 & 2 & 2.40 \\
2 & PPP & 30 & 2.29 & .28 & 2 & 2.20 \\
\hline
\end{tabular}

Based on the result delineated from the table 3.1, the students in the experimental class were likely to have a similar ability to the students in control class. It can be seen that the mean score of students' L2 spoken performance in experimental class is 2.39 and the students' L2 spoken performance is 2.29 in control class.

Table 3.2 Descriptive statistics for experimental and control class

\begin{tabular}{lllllll}
\hline No & $\begin{array}{l}\text { Teaching } \\
\text { method }\end{array}$ & N & Means & $\begin{array}{l}\text { Standard } \\
\text { deviation }\end{array}$ & $\begin{array}{l}\text { Minimum } \\
\text { score }\end{array}$ & $\begin{array}{l}\text { Maximum } \\
\text { score }\end{array}$ \\
\hline 1 & PBL & 30 & 3.01 & .49 & 2.40 & 4.20 \\
2 & PPP & 30 & 2.76 & .29 & 2.20 & 3.40 \\
\hline
\end{tabular}

In reference to the table 3.2 , the students in PBL class outperformed the students in PPP class. The mean score in PBL class reaches 3.01 with the standard deviation of .49. The minimum score of students L2 performance is 2.4 , and the maximum is 4.2. In control class, the students' spoken performance only reaches 2.76 with .29 standard deviation. The minimum score is 2.2 , and the maximum score is 3.4 .

In order to confirm whether there is a significant difference of L2 spoken performance between experimental and control group, the hypothesis testing was employed through the independent t-test. The detail of the result of independent t-test can be seen as follows:

Table 3.3 Independent t-test for Both Classes in the Posttest

\begin{tabular}{clccccc}
\hline & & $\mathrm{t}$ & $\mathrm{df}$ & $\begin{array}{l}\text { Sig. } \\
\text { (two- } \\
\text { tailed) }\end{array}$ & $\begin{array}{l}\text { Mean } \\
\text { difference }\end{array}$ & $\begin{array}{l}\text { Std.error } \\
\text { difference }\end{array}$ \\
\hline speaking & $\begin{array}{l}\text { Equal } \\
\text { Variance } \\
\text { assumed }\end{array}$ & 2.33 & 58 & .02 & 2.46 & .10 \\
& $\begin{array}{l}\text { Equal } \\
\text { Variance } \\
\text { not } \\
\text { assumed }\end{array}$ & 2.33 & 46.90 & .02 & 2.46 & .10 \\
\hline
\end{tabular}

Based on the data shown in table 3.3, since the value of two-tailed significance is $.02,(\mathrm{t}=2.33, \mathrm{df}=58)$, and it is lower than $\alpha(.05)$, the result of independent t-test can be used to reject the null $\left(h_{0}\right)$ hypothesis. In other words, there is a statistical difference of L2 spoken performance between students who learned in experimental class and those who learned in control class. This also confirms the positive effect of PBL on L2 spoken performance of students in EFB class.

\subsection{The Effect of PBL on L2 Spoken Performance}

As numerous previous studies did not concern to what extent PBL contributes to the improvement of the students L2 spoken performance, the present study attempted to explore the effect of PBL on the five speaking aspects including accent, grammar, vocabulary, fluency, and comprehension. The result can be seen from the increase of the students' score between pre-test and post-test. The detail is depicted in the following figure: 


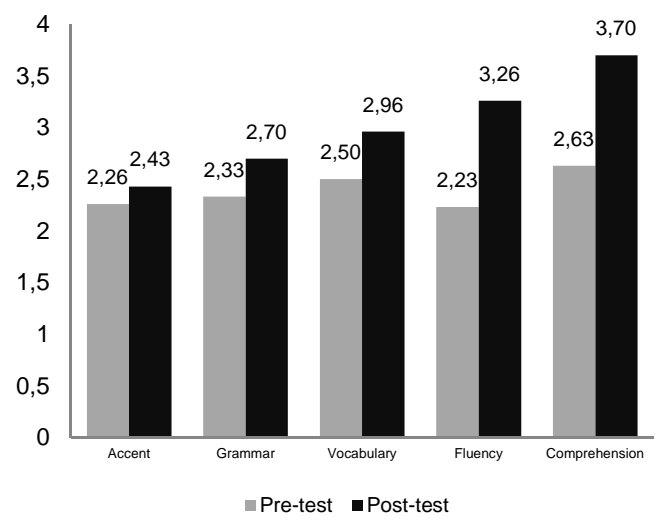

Figure 1.2 The Effect of PBL on the Five Aspects of Speaking

Based on the data delineated by the figure above, it can be seen that PBL contributes the most effect on comprehension and fluency. The students' performance in terms of comprehension increases from 2.63 to 3.7, and the students' performance improves from 2.23 to 3.26 for fluency aspect. In the aspect of vocabulary, the students' performance increases from 2.50 to 2.96 . There is also a statistical increase on grammar in which the students' performance reaches 2.33 on the pre-test, and their performance reaches 2.70 in the post-test. Lastly, the students' performance also increases from 2.26 to 2.43 in terms of accent.

\subsection{Discussion}

The findings of the present study confirm several studies on the benefits of integrating PBL to ESP and EFL contexts. First, while the process of PBL in this study deals with the integration of ICT competencies (Tyagi \& Kannan, 2013; Dooly \& Masats, 2011) such as using camera effectively, utilizing editing software, capturing, and selecting clip. Additionally, the finding of this study echoes the study conducted by Mamakouc \& Grigoriadou (2010) which found that the use of ICT-based project can be an effective method to improve students ICT skills. Moreover, the finding of this study is in line with the study conducted by Meksophawannagul (2015) in Thailand, where the use of PBL can improve engineering students' language skills as well as critical thinking and collaborative skills (Bas, 2008). The students' L2 spoken performance considerably increased after learning through PBL since in this study, the students are required to understand instruction, recognize relevant information in written and oral text, writing script or narratives to prepare for assignments, presentation, and project (Dooly \& Masats, 2010). While doing those processes, students were guided by the teacher until they could accomplish those tasks independently. The different findings of this study are that PBL contributed significant positive effects on students' L2 comprehension and fluency. This effect might be attributed to the process of language competencies (Dooly \& Masats, 2010) such as understanding instruction, recognizing the relevant information in written and oral text which helped students gaining more fluent performance and improve comprehension. Even though the increase of students' performance in terms of vocabulary, grammar, and accent is lower than comprehension and fluency, there is a notable positive effect obtained from the use of PBL during the learning process. This finding also covers the significant finding obtained from the study conducted by Alsamani \& Daif-Allah (2016) in which the use of PBL can develop English vocabulary for ESP students.

\section{CONCLUSION}

The present study focused on confirming whether or not PBL gives a positive effect on the students' L2 oral performance. The findings reveal that PBL contributes to the increase of students' L2 oral performance, especially in terms of comprehension and fluency. This result is significantly useful for several aspects. First, the adapted model can be used as the guideline for ESP practitioners to tailor their teaching practice. Second, the findings in this study somehow provide evaluative information related to the learning process and the output under the implementation of PBL for the institution where the research was carried out. The findings of this study can also become the basis for further research on exploring more benefits of PBL on ESP practice. Even though the present study has confirmed the benefits of PBL on ESP practice, several limitations were also worth considering. This article does not concern the students' perspective towards the use of PBL. The student's perspective is valuable in order to discover the benefit of PBL from the point of view of the students. This will open a new room for further study to explore the effect of PBL more comprehensively.

\section{ACKNOWLEDGEMENT}

The credit is given to School of Foreign Language (STBA) Teknokrat that has authorized the access to conduct the research and granted private fund to the writer so that the study reported in this article can be accomplished.

\section{REFERENCES}

Affandi, A., \& Sukyadi, D. (2016). Project-Based Learning and Problem-Based Learning for EFL Students' Writing Achievement at Tertiary Level. Rangsit Journal of Educational Studies 3(1), pp. 23-40.

Alsamani, A.-A. S., \& Daif-Allah, A. S. (2016). Introducing Project-based Instruction in the Saudi ESP Classroom: A Study in Qassim University. English Language Teaching. 9(1), pp. 51-64.

Al-Tamimi, N. O. M., \& Attamimi, R. A. (2014). The effectiveness of Cooperative Learning in Enhancing Speaking Skills and Attitudes towards Learning 
English. International Journal of Linguistics, 6(4), 27.

Andrade, M. S. (2016). Curricular Element for Learner Success-2 ${ }^{\text {st }}$ Century Skills. Journal of Education and Training Studies 4(8), pp. 143-149.

Bas, G. (2008). Implementation of Multiple Intelligences Supported Project-Based Learning in EFL/ESL Classrooms. Online submission. Retrieved from https://eric.ed.gov/? $q=$ gokhan + bas \&id=ED503870.

Becket, G. (2002). Teacher and student evaluations of project-based instruction. TESL Canada Journal, vol.19 no. 2, 52-66.

Dooly, M., \& Masats, D. (2010). Closing the loop between theory and praxis: new models in EFL teaching. ELT journal, ccq017.

Dooly, M., \& Masats, D. (2011). Closing the loop between Theory and Praxis: New Models in EFL Teaching. ELT Journal 65(1).pp. 42-51.

Foss, P., N., C., McDonald, K., \& Rooks, M. (2008). Project-Based Learning Activities for Short-Term for Intensive English Program. The Philippine ESL Journal 1, pp. 57-76.

Hughes, A. (2003). Testing for Language Teachers (2nd Edition). Cambridge: Cambridge University Press.

Ibrahim, A. (2010). ESP at the tertiary level: Current situation, application and expectation. English Language Teaching 3, 200-204.

Khanh, N. V. (2015). Towards Improving ESP Teaching/Learning in Vietnam's Higher Education Institutions: Integrating Project-Based Learning in ESP Courses. International Journal of Languages, Literature, and Linguistics, pp. 227-232.

Mamakou, I., \& Grigoriadou, M. (2010). An E-projectBased Approach to ESP Learning in an ICT Curriculum in Higher Education. Themes in Science and Technology Education, pp. 119-137.

Medrea, N., \& Rus, D. (2012). Challenges in Teaching ESP: Teaching Resources and Students' Need. Procedia Economics and Finance 3, pp. 1165-1169.

Meksophawannagul, M. (2015). Teacher and learner views on effective English teaching in the Thai context: The case of Engineering students. English Language Teaching, 8(11), 99.

Nakaya, K., \& Murota, M. (2013). Development and Evaluation of an Interactive English Conversation Learning System with a Mobile Device Using Topics Based on the Life of the Learner. Research and Practice in Technology Enhanced Learning, 8(1), pp. 65-89.

Nikitina, L. (2010). Video-making in the foreign language classroom: Applying principles of constructivist pedagogy. Electronic Journal of Foreign Language Teaching, 7(1), 21-31.

Noom-ura, S. (2013). Project-Based Learning and ESP: A Perfect Match. English Language Teaching 31(3), pp.1-7.
Penrod, C., Tucker, M., \& Hartman, K. (2015). Assessing Business Presentation Skills: Assuring Learning through Assessment, Analysis, and Curriculum Improvement. Journal of Behavioral Studies in Business 8, pp. 1-6.

Robinson, J. K. (2013). Project-based learning: Improving Student Engagement and Performance in the Laboratory. Analytical and Bioanalytical Chemistry 405(1), pp. 7-13.

Rodrigo, J. (2014). The Impact of Oral Communicative Strategies through Cooperative Work Activities on EFL beginner learners at Universidad de Cordoba. (Unpublished MA Thesis, Universidad de La Sabana).

Suherdi, D. (2012). Towards the 21st Century English Teacher Education: an Indonesian Perspective. Bandung: Celtic Press.

Tyagi, S., \& Kannan, R. (2013).Implementing ProjectBased Learning in Teaching English to Engineering Students. English for Specific Purposes World, 40(14). pp. 1-15.

Unal, S., Sadoglu, G. P., \& Durukan, U. G. (2014). Teacher educators' views of "model" concept and their mental models. Journal of Baltic Science Education, 13(5). 